\title{
寄 書
}

\section{石炭チャーのガス化反応速度に及ぼす乾留条件の影響}

\author{
小 島 紀 徳・山下 敏* \\ 古 澤 健 彦

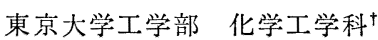

流動層ガス化炉内では, 供給された石炭はガス化雾囲 気中で急速に加熱されるとともにガス化される.このと き, 石炭中の揮発分が石炭から離脱する反応 (以下では 乾留と略称する）に要する時間は，石炭全体のガス化に 要する時間に比べて十分小さい，そこで，通常，石炭の ガス化は, 極めて迅速な乾留によるガス生成と, 乾留に より生成したチャーのガス化によるガス生成の二段階逐 次反応を仮定して解析される。また，ガス化炉の必要容 積を決定するために必要な石炭のガス化速度は, チャー のガス化速度により代表される．しかしながら，チャー のガス化反応速度として, ガス化条件とは異なるガス雾 囲気下で，かつ流動層内に打ける石炭加熱時の昇温速度 と比べてはるかに低い昇温速度の下で乾留されて生成し たチャーのガス化反応速度を用いることの妥当性につい ては十分な検討がなされているとは言い難い、すなわ ち, 乾留条件の違いが, 生成チャーのガス化反応速度拉 よびその反応の進行に伴う变化に及ぼす影響を明らかに する必要がある.

著者らはすでに流動層を用いてチャーのガス化反応速 度を, 流動層の複雑な流動条件の影響を受けずに, 生成 ガス組成の経時変化から精度よく測定できることを示し だ、流動層を用いれば，熱天科では実現できない速い 昇温速度の下で乾留・生成したチャーのガス化速度の測 定が可能である，高温のガス化雾囲気下で石炭を乾留 し，チャーを製造することは，乾留と同時に乾留により 生成したチャーのガス化反応が起こるため, 困難である が, 流動層内では石炭は急速に加熱されるので, 乾留と ガス化が同時に進行する場合のガス化雾团気下で乾留・ 生成したチャーのガス化速度を, 石炭のガス化速度と乾 留速度の差として定義することにより測定することも可 能となる. 本報告では上記の流動層内の種々の雾囲気下 で乾留した場合をも含む種々の条件で乾留・生成したチ ャ一のガス化速度を, 太平洋炭について流動層を用いて 測定し, 乾留条件の違いがチャーの初期掞よび種々の反 応率に拉けるガス化反応速度に及ぼす影響を検討した。

実験方法実験方法の大部分については前報1で詳

$+\mp 113$ 文京区本郷 7-3-1

* 東京ガス(株)
しく報告したので，以下に異なる点だけを記す，試料と しては $500 \sim 1000 \mu \mathrm{m}$ にふるいわけをした太平洋炭を 用いた. その分析值を Table 1 に示す.

乾留ーガス化実験は以下の三法により行った。ここで チャーのガス化はいずれも $1273 \mathrm{~K}, \mathrm{CO}_{2} 20 \%\left(\mathrm{~N}_{2}\right.$ 80\%) の条件で流動層内で行った。 ガス流速は流動層流 動媒体の流動化開始速度の 6 倍とした．また，チャーの ガス化速度を 45 分間測定した後末反応炭素量を燃焼に より求め, 前報 ${ }^{1)}$ と同様にチャ一中の初期炭素量を算出 した.

1) 流動層内乾留チャーのガス化; 乾燥させた太平洋 炭 $0.500 \mathrm{~g}$ を $1273 \mathrm{~K}$ 窒素雾囲気の流動層に投入し, 10 分間乾留した (乾留条件 $\mathrm{A})$. 流動化ガスを窒素希釈 $\mathrm{CO}_{2}$ ガスに切り換え, 引き続きガス化を行った.

な怙一部の実験では 10 分間の乾留の後も引き続き乾 留を行い(乾留条件 $\mathrm{A}^{\prime}$ ), 生成ガスの経時変化を測定し た. 乾留による生成ガスは， $\mathrm{CH}_{4}, \mathrm{CO}_{2}, \mathrm{CO}$ であった が，炭化水素については乾留開始の 30 秒後に CO の 約 $1 / 20$ の $\mathrm{CH}_{4}$ が検出された他は検出されなかった. また, 乾留開始の 10 分後に打ける, 乾留による CO の 生成速度は $2 \times 10^{-6} \mathrm{~mol} / \mathrm{s}$ 以下であり, 乾留条件 $\mathrm{A}$ の下 で生成したチャーのガス化による CO 生成速度に比べ て十分小さく，無視することができた.

2）流動層内同時乾留一ガス化; 乾燥させた太平洋炭 $0.500 \mathrm{~g}$ を $1273 \mathrm{~K}, \mathrm{CO}_{2} 20 \%\left(\mathrm{~N}_{2} 80 \%\right)$ の条件下の 流動層に直接投入した. このとき, 石炭の乾留とチャー のガス化はガス化雾囲気下で同時に進行する．このよう な条件下で乾留し(乾留条件 B), 生成したチャーのガ ス化速度を, 他の乾留条件下で生成したチャーのガス化 速度と比較するため, 石炭のガス化速度と石炭の乾留速 度の差として定義し, 以下の評価を行った。

前記のように, 乾留条件 $\mathrm{A}^{\prime}$ の下では炭化水素の生成 はほとんどみられない。したがってガス化条件下で乾留 を行った場合も, $\mathrm{CO}_{2}$ と炭化水素との気相反応により， $\mathrm{CO}$ が生成することはないと仮定できる，そこで，本実 験により得られた，石炭のガス化によるCO の全生成 速度から, 乾留条件 $\mathrm{A}^{\prime}$ による CO の生成速度を差し 引いた值を, 乾留条件 $\mathrm{B}$ の下で生成したチャーのガス化 
Table 1 Proximate and ultimate analysis of Taiheiyo coal

\begin{tabular}{|c|c|c|c|c|c|c|c|}
\hline \multirow{2}{*}{$\begin{array}{c}\text { Moisture } \\
\text { wt \% }\end{array}$} & \multicolumn{3}{|c|}{ Proximate, wt $\%$, dry } & \multicolumn{4}{|c|}{ Ultimate, wt $\%$, d.a.f. } \\
\hline & F.C. & V.M. & Ash & C & $\mathbf{H}$ & $\mathbf{N}$ & $O$ (dif.) \\
\hline 5.3 & 39.5 & 44.4 & 16.1 & 77.0 & 6.2 & 1.2 & 15.6 \\
\hline
\end{tabular}

Table 2 Devolatilization conditions investigated

\begin{tabular}{llc} 
& Heating rate, $\mathrm{K} / \mathrm{s}$ & Time kept at $1273 \mathrm{~K}, \mathrm{~s}$ \\
\hline A & $\begin{array}{l}\text { rapid in the } \\
\text { fluidized bed } \\
\text { rapid in the } \\
\text { fluidized bed }\end{array}$ & 600 \\
B & 12 & $\begin{array}{c}\text { (devolatilization in } \\
\text { gasification condition) }\end{array}$ \\
C & 12 & 3600 \\
D & 4 & 600 \\
E & 2.3 & 2400 \\
F & 1.5 & 2400 \\
G & 0.33 & 2400 \\
H & 0.08 (for $\sim 673 \mathrm{~K}$ ) & 600 \\
I & 0.33 (for $673 \mathrm{~K} \sim$ ) & 2400 \\
& 0.08 (for $\sim 873 \mathrm{~K}$ ) & 2400 \\
J & 0.33 (for $873 \mathrm{~K} \sim$ ) & \\
\hline
\end{tabular}

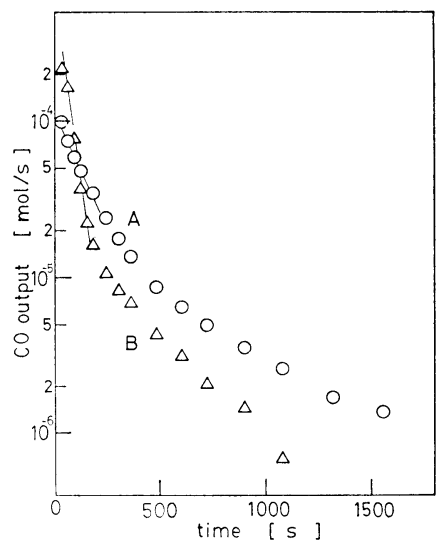

Fig. 1 Effect of simultaneous devolatilization on time variation of carbon monoxide output

\section{による $\mathrm{CO}$ の生成速度として評価した.}

3）種々の昇温速度の下で乾留・生成したチャーのガ ス化; 乾燥した太平洋炭約 $5 \mathrm{~g}$ を石英ウールに乗せ, 窒 素気流下の乾留灿* 内に执いて, 種々の昇温速度の下で 乾留した（乾留条件 $\mathrm{C} \sim \mathrm{J}$ )。これらの乾留条件を，乾留 条件 A，B と合わせて Table 2 に示す. 室温窒素気流 中で室温まで泠却した後, 生成チャー0.500 g をガス化 条件下の流動層に投入し, ガス化した。

以下の図中では, 乾留条件を $\mathrm{A} \sim \mathrm{J}$ の記号により示 す.

ガス化雾囲気中で，石炭の乾留とチャーのガス化が同 時に進行する場合と，乾留後にチャーをガス化する場合 とのチャーのガス化速度の違い 流動層内において乾

* 種々の乾留時昇温速度を達成するため, 前報1)と同一の乾留炉を用い た。試料中に裸の熱電対を㨂入し, 試料温度を制御するとともに湖定 した.

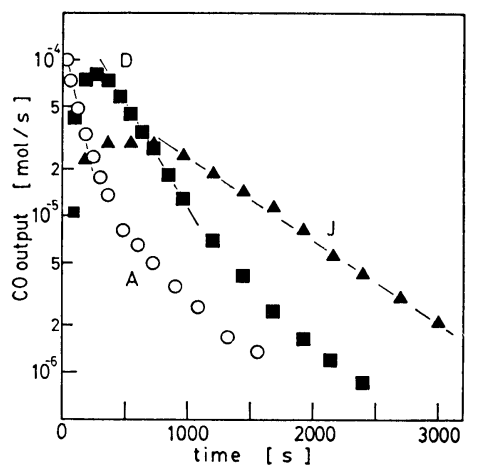

Fig. 2 Effect of heating rate in devolatilization on time variation of carbon monoxide output

留条件 $\mathrm{A}$ の下で生成したチャーをガス化したときの CO の生成速度の経時変化および, 石炭を直接ガス化雰囲気 の流動層に投入した実験から前述の方法により求めた， 乾留条件 B の下で生成したチャーのガス化によるCO の生成速度の経時变化を合わせて Fig. 1 亿示す.な お，いずれの条件の場合も繰り返し実験により再現性は 確認されている. Fig. 1 より, 乾留条件 B の下で生成 したチャ一のガス化速度は, 乾留条件 $\mathrm{A}$ の下で生成した チャーのガス化速度に比べ大きいことがわかる. 両者の 乾留時の昇温速度は等しいが, 乾留条件 A では窒素雾囲 気中であるのに対し乾留条件 Bではガス化雾囲気中で乾 留が起こっており, さらに, 乾留条件 Bでは, 乾留によ る揮発分の脱離と同時にチャーのガス化も進行する.こ れらの違いが，チャーのガス化速度に影響する機構につ いては, 今後の検討課題である.

乾留時における昇温速度がチャ一のガス化速度に及ぼ す影響乾留条件 C J の下で太平洋炭を乾留した結 果, いずれの条件下においても乾留による重量減少は乾 量基準で 42 43\% であり, 工業分析による揮発分とほ ぼー致した。

乾留炉内で乾留生成したチャーのガス化によるCO 生成速度の経時変化の例を, 乾留条件 $\mathrm{D}, \mathrm{J}$ の場合につ いて Fig. 2 に示す. 乾留時の昇温速度が速い D の方 が, 昇温速度が遅いJに比べ，チャーのガス化速度が大 きいことがわかる.ささらに, 流動層内で急速に昇温, 乾 留し，(乾留条件A）生成したチャーのガスを行った場 合の結果を Fig. 2 に合わせてプロットし, 比較する と, 上述の Dの場合よりもさらに大きいガス化速度を示 した、流動層内に投入された原炭粒子の昇温速度は実測 できなかったが，粒子は層内で瞬時に分散され，周囲の 


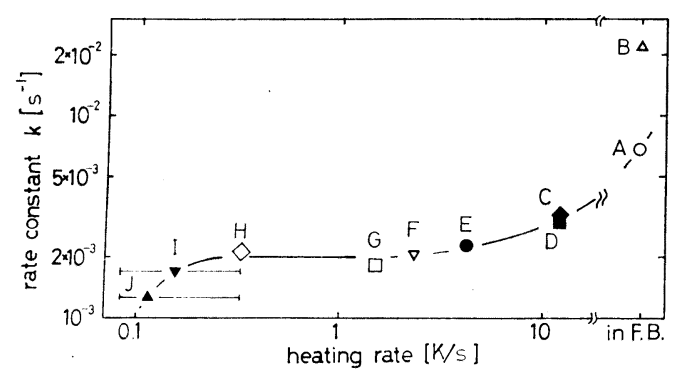

Fig. 3 Effect of heating rate on initial gasification reaction rate constant, $k$

固体から急速に熱を供給されるので, 乾留条件 C J のいずれよりも大きい昇温速度の下で乾留されると考え られる.これらのことから, 乾留時における昇温速度が 大きい、核どチャーのガス化速度は大きい傾向がみられる ことがわかる。

なお, 乾留時の昇温速度が $12 \mathrm{~K} / \mathrm{s}$ の場合について

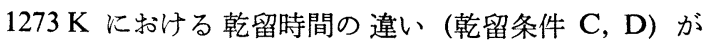
ガス化速度に及ぼす影響も検討したが，違いは認められ なかった。

チャーの初期ガス化反応速度定数に及ぼす乾留時の昇 温速度の影響 前項に示した傾向を定量的に評価する ため，すべての結果から，前報1)に示した方法を用いて チャ一の初期ガス化反応速度定数, $k$ を求め, Fig. 3 に乾留時の昇温速度に対してプロットした，昇温速度を 途中で変えた場合（乾留条件 I, J) については便宜上 平均の昇温速度を横軸に用いた。昇温速度が大きいほど 初期反応速度定数は大きいが, 昇温速度が極めて大きい 場合と極めて小さい場合に昇温速度の影響が顕著にみら れた.

種々のチャーの反応率に掓るチャーのガス化速度に 及ぼす乾留条件の影響 前報1で示した方法により求 めた層内初期炭素量で各時間における積算反応量を除す ことにより反応率， $X$ を求めた． CO の生成速度から 求めた反応率の変化率, $d X / d t$ を, 反応率に対してプロ ットした一例を Fig. 4 に示す. 乾留時の昇温速度が大 きいほどチャーのガス化反応速度が大きいことが，すべ ての反応率にわたり見られる. 寸なわち, 昇温速度の違 いは，チャーの初期ガス化反応速度ばかりではなく，チ ャ一の反応率が高い領域のガス化反応速度にまで影響を 与えていることがわかる.なお，ここには示さないが， 乾留時におけるガス雾囲気の違い，すなわち乾留時にお ける同時に進行するガス化反応の有無（乾留条件 A, B) もチャ一の反応率が高い領域までガス化反応速度に影響 を及ぼすことがわかった。

\section{結言}

太平洋炭を種々の昇温速度の下で乾留して生成したチ

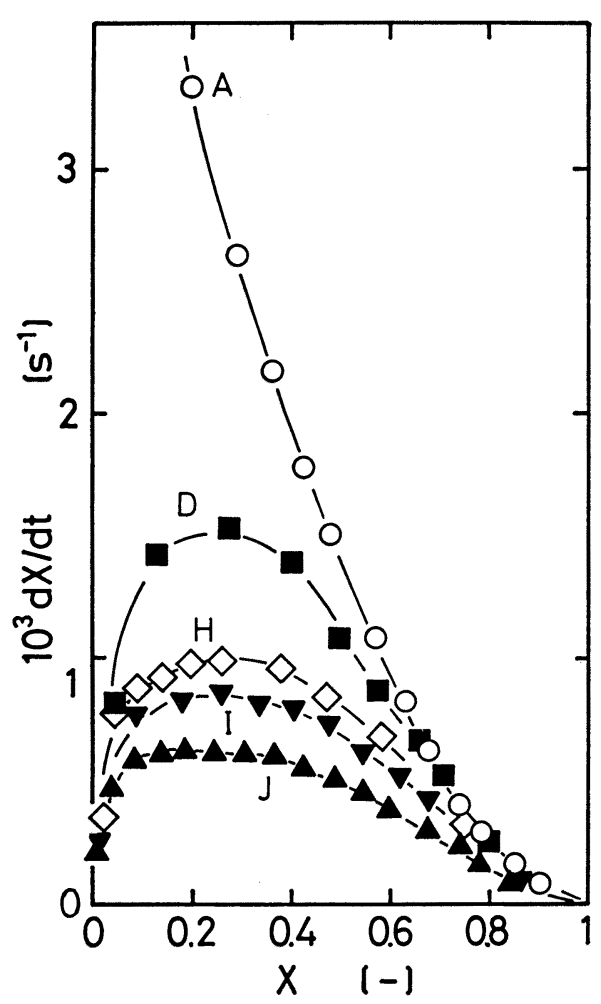

Fig. 4 Effect of devolatilization condition on dynamic change in conversion rate

ヤーおよび太平洋炭を, 流動層内において $\mathrm{CO}_{2}$ でガス 化し, チャーのガス化反応速度に及ぼす乾留条件の影響 を検討した. 石炭を直接ガス化したときのチャーのガス 化速度を, 石炭のガス化速度と石炭の窒素雾囲気下での 乾留速度との差として定義して測定した值は, 流動層内 で急速に乾留, 生成したチャーのガス化速度より大きか った.すなわち, 乾留がガス化雾团気中で起こり, 乾留 とチャーのガス化が同時に進行する場合, チャーのガス 化速度は大きくなる, また, 乾留によりチャーを生成 し, 生成したチャーをガス化した場合には, 流動層内で 急速に昇温, 乾留した生成したチャーのガス化速度が最 も大きく, 乾留時の昇温速度を減少させるとチャーのガ ス化速度も減少した. さらに, 上記の乾留条件の影響 は, ガス化反応の初期ばかりではなく, チャーの反応率 が高い領域にまで及ぶことが明らかとなった。

これらのことから, 従来から多くの研究者により測定 されている, 低速度で昇温, 乾留して生成したチャーの ガス化速度を, 直接流動層石炭ガス化炉の設計, 解析に 用いることには問題があると考えられる。

[謝辞]本研究は文部省科学研究費 (エネルギー 特別研究・石炭のガス化, 58040009, 59040033) の援助 を受けて行われた。ここに記して感謝します。 


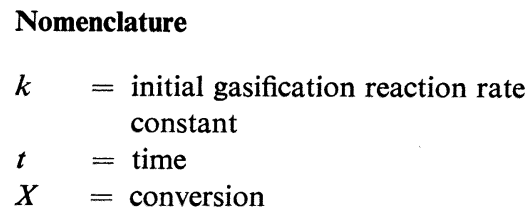

$\left[\mathrm{s}^{-1}\right]$

[s]

$[-]$

\section{Literature cited}

1) Kojima, T., T. Furusawa and D. Kunii: Kagaku Kogaku Ronbunshu, 10, 596 (1984)

(1984 年 11 月 9 日受理; 化学工学協会第 48 年会 (京都, 1983 年 4 月), 化学工学協会第 17 回秋季大会 (仙台, 1983 年 9 月)にて一部発表)

\title{
Effects of Devolatilization Condition on Gasification Rate of Coal Char
}

\author{
Toshinori Kojima, Satoshi Yamashita* and Takehiko Furusawa \\ Dept. of Chem. Eng., Faculty of Eng., Univ. of Tokyo, Tokyo 113
}

\begin{abstract}
Key Words: Energy, Coal Char, Gasification Rate, Fluidized Bed, Devolatilization
The $\mathrm{CO}_{2}$ gasification rates of Taiheiyo coal chars obtained under various devolatilization conditions were measured by use of a fluidized bed. The gasification rate of char was enhanced by an increased heating rate in the devolatilization process. The gasification rate of char when the coal was gasified in the fluidized bed was determined from the difference between the gas produced from gasification of coal and that from devolatilization of coal under nitrogen atmosphere. The rate thus determined was greater than the rate of char obtained by devolatilization at a rapid heating rate in the fluidized bed under nitrogen atmosphere. Namely, the gasification rate of char obtained by devolatilization under the condition where the devolatilization of coal and the gasification of char take place simultaneously was one order of magnitude greater than the rate of char obtained by devolatilization at reduced heating rate from 0.08 to $0.33 \mathrm{~K} / \mathrm{s}$. The effects of the devolatilization condition on the gasification rate of char were found not only in the rate of char of lower conversion but also in the rate of char of higher conversion.
\end{abstract}

* Tokyo Gas Co., Ltd.

\section{上向並流，向流および下向並流式気泡塔における流動特性}

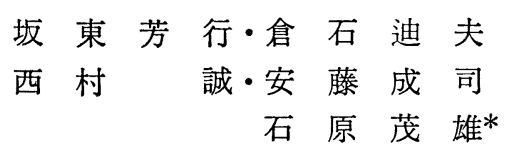

岐皁大学工学部 工業化学科 ${ }^{\dagger}$
気泡塔の流動状態, ガスホールドアップに及ぼす操作 条件の研究は古くから行われており, 加藤 ${ }^{8}$, Zuber $5^{15)}$ の定量的検討以来, 多くの実験および解析が報告さ れている1,14). しかし，これまでの研究の多くは上向並 流に関するものであり，下向液流れの系については，藤 江 $5^{6)}$, Friedel $5^{5)}$, Clark $5^{4)}$ の下向並流, Bridge $5^{3)}$, Bhaga $5^{2)}$, 大竹 ${ }^{13)}$ の向流など, 少数の研究が 報告されているに過ぎない. しかもこれらの研究は, 安

+ 干501-11 㪁阜市柳戸 1-1

* 日精工業(株)
定な下向並流あるいは向流域にて行われており，これら の流れの境界についてほとんど触れられていない.

そこで本研究では, 特に下向並流と向流との境界に注 目して，どのような気液速度においてこれらの境界が現 れるかを調べ, 気液の種々の流れ方向の存在する領域図 を作成した.ささら，一連の実験として，液流れなしお よび上向並流まで含めた条件で, 同一装置にて流動状態 の観察およびガスホールドアップの測定を行ったとこ ろ, 任意の気液速度における流動状態およびガスホール ドアップについて, 上向並流から下向並流に及ぶ全範囲 


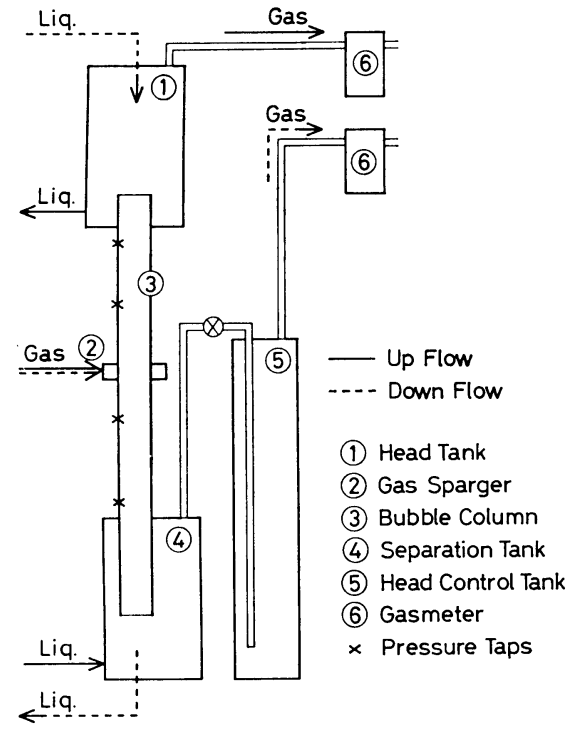

Fig. 1 Experimental apparatus

にわたって，同一手法で解析し得ることが明らかになっ た.

この手法と上記領域図を適用することにより，与えら れた気液速度に対して, 気液の流れ方向, 流動状態およ びガスホールドアップの子測が可能である.

\section{実験装置および方法}

下向並流と向流の境界を知ることを主目的とし，あわ せて上向並流の実験も行い得るように，バルブの切替の みにより 3 種の流れ方向が可能となる装置を製作した.

実験装置の概略を Fig. 1 に示す. 気泡塔は透明アク リル樹脂製で，内径は $114 \mathrm{~mm}$ および $78 \mathrm{~mm}$ ，塔高は いずれも $5000 \mathrm{~mm}$ の 2 種類であり, 塔頂にはヘッドタ ンク，塔底には気液分離タンクを備えている．ガス分散 器は，吹さ込まれた気泡に方向性を与えぬことおよび塔 内に障害物を置かぬことを目的として，塔壁の円周上に 直径 $0.5 \mathrm{~mm}$ の孔を約 $4 \mathrm{~mm}$ の等間隔で数十個あけ, その外周に蓄気室を設けた構造とし，塔高のほぼ中央部 に設置した. 塔壁には静圧測定用タップをガス分散器よ り上方おょび下方に $1000 \mathrm{~mm}$ 間隔で 2 個ずつ取付け た. また, 分散器側のタップとガス分散孔との距離は $800 \mathrm{~mm}$ と大きくした.これは，特に低ガス流量の場 合, 吹き込まれた気泡は塔断面に均一に分散しないが, $500 \mathrm{~mm}$ 程度下流ではほぼ均一分散となることが観察さ れたためである。

実験には水道水おょび空気を用い, 次の手順で行っ た.ガスおよび夜流量を所定量に調節し，定常状態にな ったのち，流動状態を観察し，各流量およびタップ間の 水頭差を測定した. この操作を，ガス空塔速度 $-0.1 \leq$ $u_{G 0} \leq 0.3 \mathrm{~m} \cdot \mathrm{s}^{-1}$, 液空塔速度 $-0.8 \leq u_{L 0} \leq 0.2 \mathrm{~m} \cdot \mathrm{s}^{-1}$ に

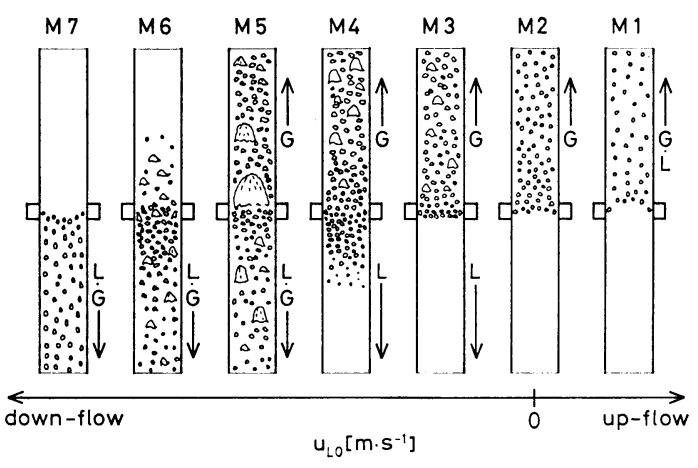

Fig. 2 Model of flow mode

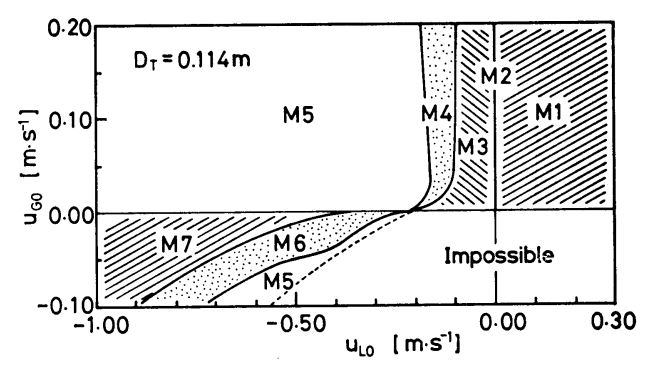

Fig. 3 Region of flow mode, M1 M7 shown in Fig. 2

て行った $\left(u_{G 0}, u_{L 0}\right.$ ともに上向流れを正とする).

ガスホールドアップ $\varepsilon_{G}$ は, タップ間距離 $\Delta z$ および タップ間の水頭差 $\Delta h$ を用いて次式から算出した

$$
\varepsilon_{G}=\Delta h / \Delta z \pm 4 f u_{L 0}{ }^{2} / 2 g D_{T}
$$

ここで, 右辺第 2 項は液流れによる単位長さ当りの摩擦 損失を表しており, 符号は上向流れの場合は正, 下向流 れの場合は負となる.

\section{結果および考察}

気液の流れ方向 ガス速度を一定として液速度を減 少（下向流れの場合は増加）させていく場合に観察され た気液の流れ方向の模式図を Fig. 2 に示す.

$\mathrm{M} 1$ は気液上向並流 $\left(u_{L 0}>0\right), \mathrm{M} 2$ は液流れなし $\left(u_{L 0}\right.$ $=0)$ の状態である. 液流れが下向 $\left(u_{L 0}<0\right)$ の場合には, M3〜M7 の様式が観察された.

M3，M4 はともに供給したガスが上向に流れる向流 であるが，M3 ではガス分散器より下に気泡は滞在せ ず，また M4 ではガス分散器より下に気泡が滞在し， 静止あるいは循環運動（ガス分散器と塔底との間におけ る上下運動）を行らが，気泡は塔底部に備えた気液分離 タンクヘは流れない. M5 は, 供給したガスの一部が上 向に, 残りが下向に流れる状態で, 向流と下向並流の共 存系である. M6, M7 はともに下向並流であり，M7 ではガス分散器より上に気泡は滞在しない.M6 では， 合体した大気泡がガス分散器より上に流れ，上昇中分裂 して小気泡となり，下部に戻されるといら気泡循環運動 が観察されるが, 気泡は塔頂部の気液分離タンクヘは流 


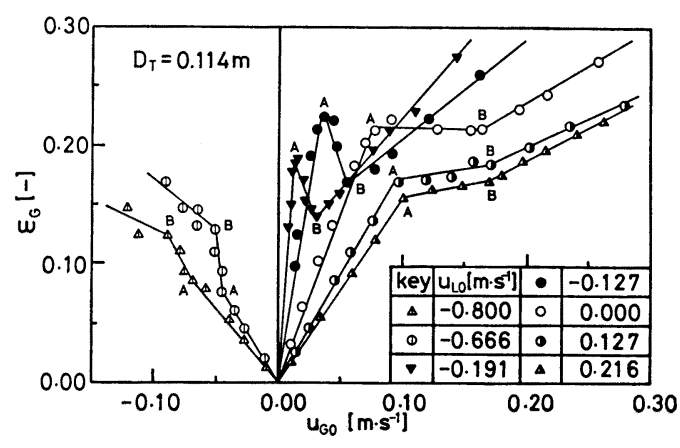

Fig. 4 Effect of gas and liquid velocities on gas holdup れない.

液の流れが下向の場合 $(\mathrm{M} 3 \sim \mathrm{M} 7)$ には, 液の真速度 $\left[u_{L 0} /\left(1-\varepsilon_{G}\right)\right]$ の絶対值と気泡の上昇速度の大小関係によ り, 気泡の移動方向が決まる. 気泡の上昇速度は, 気泡 径が大きくなるにつれて大きくなる10). 本装置において は気泡径にかなりの分布があり, ガス流量が大きい場合 には合体した大気泡あるいはスラッグも存在する.この ため, ガスの上向流れから下向流れの間に, このよらな 過渡的段階が観察されることになる.

種々の気液速度に対し, Fig. 2 に示した M1〜M7 の各気液の流れ方向が現れる領域を Fig. 3 に示す. M3 M7 の各領域の境界線は，流れの方向を判別する のに便利であり, 特定の装置, 特定の系については,

Fig. 3 のように決定できる. しかし, これらの境界線 は, 装置の構造などによって, 傾向は同じであるが位置 がかなり移動する．このために，これらを気液速度のみ によって表示することはできなかった.

流動状態, ガスホールドアップと気液速度流動状 態は, ガス速度と液速度の組合せにより変化する. 本研 究では流動状態を, 小気泡が比較的均一に分散している Bubble Flow (BF), 局所的に気泡の合体が始まる Transient Flow (TF) および 合体した大気泡の存在割 合が多くなり，スラッグも発生する Churn Turbulent Flow (CTF) の 3 種に大別した.

液速度一定の条件における内径 $114 \mathrm{~mm}$ 塔のガスホ ールドアップとガス速度の関係を Fig. 4 に示す. 気液 の流れ方向が上向下向のいずれであっても，本実験の液 速度の範囲では, ガス流量増加に伴うガスホールドアッ プの変化は, それぞれ傾斜の異なる 3 本の直線で近似で きた. 傾きの変わる点の低ガス流量側を $\mathrm{A}$, 高ガス流量

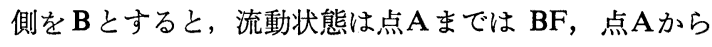
$\mathrm{B}$ をでは $\mathrm{TF}$, 点 $\mathrm{B}$ 以降は $\mathrm{CTF}$ であることが観察され た.

次に, BF, TF および CTF に関して, 気液の相対速 度 $u_{S}\left[=u_{G 0} / \varepsilon_{G}-u_{L 0} /\left(1-\varepsilon_{G}\right)\right]$ と $u_{L 0}$ と $D_{T}$ から成る無次 元数 $\left(u_{L 0} / \sqrt{g D_{T}}\right)$ の関係を Fig. 5 にプロットした.

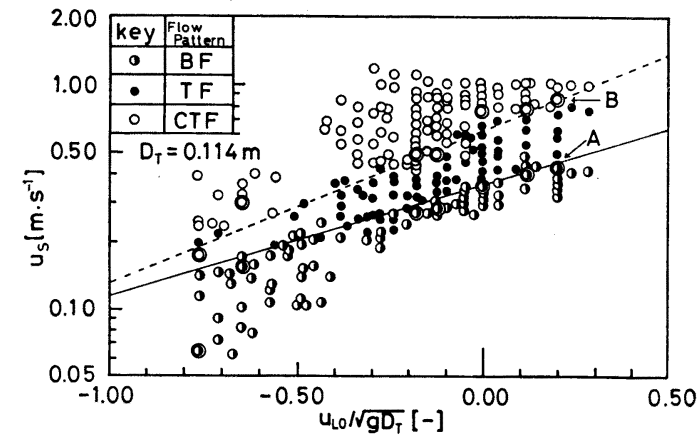

Fig. 5 Plot of gas-liquid slip velocity against $u_{L 0} / \sqrt{g D_{T}}$

図には，Fig. 4 の点 A, B に拈りる $u_{S}$ を二重丸にて 併記した. Fig. 5 において, 同一 $u_{L 0} / \sqrt{g D_{T}}$ では BF, TF， CTF の順に相対速度が大きくなっている．また， 点 $\mathrm{A}$ の $u_{S}$ は $\mathrm{BF}$ の存在する上限值に, 点 $\mathrm{B}$ の $u_{S}$ は CTF の存在する下限值にほぼ一致している. ここ で, BF の存在する上限值を $u_{S A}, \mathrm{CTF}$ の存在する下 限值を $u_{S B}$ とすると, 多少の例外点を除さ次のように 表すことができた。

$$
\begin{gathered}
u_{S A}=0.36 \exp \left(1.14 u_{L 0} / \sqrt{g D_{T}}\right) \\
\left(-0.76 \leq u_{L 0} / \sqrt{g D_{T}} \leq 0.19\right) \\
u_{S B}=0.61 \exp \left(1.56 u_{L 0} / \sqrt{g D_{T}}\right) \\
\left(-0.76 \leq u_{L 0} / \sqrt{g D_{T}} \leq 0.19\right)
\end{gathered}
$$

Eqs. (2) および (3) を Fig. 5 に実線および破線で示し た.また, Fig. 5 と同様のプロットを内径 $78 \mathrm{~mm}$ 塔 のデータについて行った結果, この場合の $u_{S A}$ および $u_{S B}$ も Eqs. (2) および (3) で表すことができた.

内径 $114 \mathrm{~mm}$ および $78 \mathrm{~mm}$ 塔の BF および CTF におけるガスホールドアップは, Nicklin ら ${ }^{12)}$, Zuber ら

$\mathrm{BF}: \varepsilon_{G}=u_{G 0} /\left[0.27+1.20\left(u_{G 0}+u_{L 0}\right)\right]$

CTF: $\varepsilon_{G}=u_{G 0} /\left[0.53 \sqrt{g D_{T}}+1.36\left(u_{G 0}+u_{L 0}\right)\right] \quad$ (5)

流動状態の判定とガスホールドアップの算出 任意 の気液速度に扣ける気液の流れ方向は Fig. 3 より判定 できる．流動状態拉よびガスホールドアップは，以下の ようにして求められる. まず, Eq. (4) より BF のガス ホールドアップ $\varepsilon_{1}$ を求め, この $\varepsilon_{1}$ に拈ける $u_{S}$ が Eq. (2)による $u_{S A}$ より小さいならば, 流動状態は BF で あると判断し，ガスホールドアップは $\varepsilon_{1}$ とする. $\varepsilon_{1}$ に おける $u_{S}$ が $u_{S A}$ より大きいときは, Eq. (5)より CTF のガスホールドアップ $\varepsilon_{2}$ を求め, この $\varepsilon_{2}$ における $u_{S}$ が Eq. (3) による $u_{S B}$ より大さいならば，流動状態は $\mathrm{CTF}$ ，ガスホールドアップは $\varepsilon_{2}$ とする， $\varepsilon_{2}$ における $u_{S}$ が $u_{S B}$ より小さいときは, 流動状態は TF であると する．TF におけるガスホールドアップは，同一液速度 における $u_{S A}$ と $u_{S B}$ に相当する 2 点 $\left(u_{G 0}, \varepsilon_{G}\right)$ の間で 
Table 1 Experimental data available in the literature

\begin{tabular}{|c|c|c|c|c|c|}
\hline Reference & Type of flow & $D_{T}[\mathrm{~m}]$ & Sparger & $\begin{array}{c}\text { Superficial } \\
\text { velocities }\left[\mathrm{m} \cdot \mathrm{s}^{-1}\right]\end{array}$ & Gas-liquid system \\
\hline Clark et al. 4) & $\uparrow \uparrow$ and $\downarrow \downarrow$ & 0.052 & (mixing flow) & $\begin{array}{l}-3.3<u_{G 0}+u_{L 0}<3.3 \\
\left(R e_{L}=4 \times 10^{4} \sim 1.6 \times 10^{5}\right)\end{array}$ & air-water \\
\hline Koide et al. 9) & $\uparrow \uparrow$ & $\begin{array}{l}0.05 \\
0.10 \\
0.20\end{array}$ & $\begin{array}{l}\text { porous plate } \\
\text { perforated plate }\end{array}$ & $\begin{array}{l}0<u_{G 0}<0.062 \\
0<u_{L 0}<0.022\end{array}$ & $\begin{array}{l}\text { air-water, } \\
\text { alcohol solutions }\end{array}$ \\
\hline Fujie et al. 6) & $\downarrow \downarrow$ & 0.45 & $\begin{array}{l}\text { porous tube } \\
\text { perforated tube }\end{array}$ & $\begin{array}{l}-0.010<u_{G 0}<0 \\
-0.23<u_{L 0}<-0.15\end{array}$ & air, oxygen-water \\
\hline Otake et al. 13) & $\uparrow \uparrow$ and $\downarrow \uparrow$ & 0.05 & $\begin{array}{l}\text { multi nozzle } \\
\text { single nozzle }\end{array}$ & $\begin{array}{l}0<u_{G 0}<0.08 \\
-0.15<u_{L 0}<0.15\end{array}$ & $\begin{array}{l}\text { air-pure water, } \\
\text { alcohol solutions }\end{array}$ \\
\hline
\end{tabular}

\section{一次の関係が成り立つとして計算する.}

内径 $114 \mathrm{~mm}$ 塔における ガスホールドアップの 測定 值と, 本計算手法による計算值ならびに既往の実験式に よる計算值との比較を, Fig. 6 に示す. 比較の対象と した研究における実験条件を Table 1 にまとめた.

いずれの実験式も, それが求められた気液速度の範囲 では，測定値とよく一致しているが，その範囲を越える と必ずしもよい一致はみられない，これに対して，本計 算手法による計算值は, 簡単な実験式に基ついているに もかかわらず，上向並流から下向並流に至る全測定值を 良好に説明しており，さらに流動状態も判定できる.

\section{Nomenclature}

$$
\begin{aligned}
& D_{T}=\text { diameter of bubble column [m] } \\
& f=\text { friction factor [-] } \\
& g=\text { gravitational acceleration }\left[\mathrm{m} \cdot \mathrm{s}^{-2}\right] \\
& \Delta h=\text { manometric difference between taps [m] } \\
& u_{G 0}=\text { superficial gas velocity }\left[\mathrm{m} \cdot \mathrm{s}^{-1}\right] \\
& u_{L O}=\text { superficial liquid velocity } \quad\left[\mathrm{m} \cdot \mathrm{s}^{-1}\right] \\
& u_{S}=\text { gas-liquid slip velocity } \quad\left[\mathrm{m} \cdot \mathrm{s}^{-1}\right] \\
& u_{S A}=\text { gas-liquid slip velocity at boundary } \\
& \text { between BF and TF }\left[\mathrm{m} \cdot \mathrm{s}^{-1}\right] \\
& u_{S B}=\text { gas-liquid slip velocity at boundary } \\
& \text { between TF and CTF }\left[\mathrm{m} \cdot \mathrm{s}^{-1}\right] \\
& \Delta z=\text { distance between taps [m] } \\
& \varepsilon_{G} \quad=\text { gas holdup } \quad[-]
\end{aligned}
$$

\section{Literature cited}

1) Akita, K. and F. Yoshida: Ind. Eng. Chem. Process Des. Develop., 12, 76 (1973)

2) Bhaga, D. and M. E. Weber: Can. J. Chem. Eng., 50, 323, 329 (1972)

3) Bridge, A. G., L. Lapidus and J. C. Elgin: AIChE J., 10,

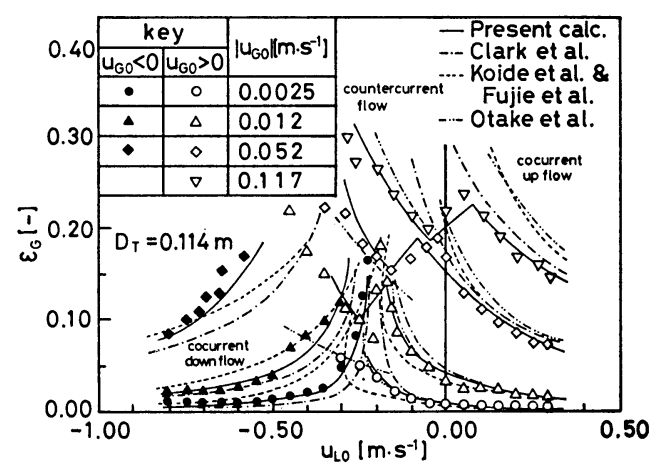

Fig. 6 Comparison of the calculated results with the measured data

819 (1964)

4) Clark, N. N. and R. L. C. Flemmer: Chem. Eng. Sci., 39, 170 (1984)

5) Friedel, L., P. Herbrechtmeier and R. Steiner: Ger. Chem. Eng., 3, 342 (1980)

6) Fujie, K., M. Takaine and H. Kubota: J. Chem. Eng. Japan, 13, 188 (1980)

7) Hills, J. H.: Chem. Eng. J., 12, 89 (1976)

8) Kato, Y.: Kagaku Kögaku, 26, 1068 (1962)

9) Koide, K., T. Hirahara and H. Kubota: ibid., 30, 712 (1966)

10) Kubota, M., T. Akehata and T. Shirai: ibid., 31, 1074 (1967)

11) Maruyama, T., T. Yoshida and T. Mizushina: J. Chem. Eng. Japan, 14, 352 (1981)

12) Nicklin, D. J., J. O. Wilkes and J. F. Davidson: Trans. Instn. Chem. Engrs., 40, 61 (1962)

13) Otake, T., S. Tone and K. Shinohara: J. Chem. Eng. Japan, 14, 338 (1981)

14) Shar, Y. T., B. G. Kelkar, S. P. Godbole and W.-D. Deckwer: AIChE J., 28, 353 (1982)

15) Zuber, N. and J. A. Findlay: Trans. ASME, J. Heat Transfer, 87, 453 (1965)

(1985 年 2 月 25 日受理; 化学工学協会第 49 年会 (名古屋, 1984 年 4 月) にて発表) 


\title{
Flow Characteristics in Bubble Columns with Cocurrent Upflow, Countercurrent Flow and Cocurrent Downflow
}

\author{
Yoshiyuki Bando, Michio Kuraishi, Makoto Nishimura, \\ Seiji Ando and Shigeo Ishihara* \\ Dept. of Ind. Chem., Gifu Univ., Gifu 501-11
}

Key Words: Chemical Reactor, Bubble Column, Gas Holdup, Flow Pattern, Bubble Flow, Churn Turbulent Flow, Slip Velocity

Flow pattern observations and gas holdup measurements were made at various gas and liquid rates, using 114-mm and 78-mm diameter, bubble columns of 5000-mm height.

Taking special notice of the boundary between countercurrent flow and cocurrent downflow, a region of gas-liquid flow mode is shown in a diagram. The flow pattern for a given condition was judged from the gas-liquid slip velocity.

Using the above diagram and the empirical equations for slip velocity and gas holdup, the flow mode, flow pattern and gas holdup can be estimated for any condition.

* Nissei Kogyo Co. 